\title{
Erken Çocukluk Öğretmenlerinin Acil Uzaktan Eğitime İlişkin Görüşleri
}

\section{Early Childhood Teachers Views on Emergency Remote Teaching (ERT)}

https://doi.org/10.52105/temelegitim.3.2.1

\author{
Ayfer Nur AYKAR ${ }^{1}$ \\ https://orcid.org/0000-0001-6050-6028 \\ Ibrahim Halil YURDAKAL ${ }^{2}$ \\ https://orcid.org/0000-0002-6333-5911
}

Geliş Tarihi/Received: 08/01/2021 Kabul Tarihi/Accepted: 04/04/2021 Yayın Tarihi/Published: 15/04/2021

\begin{abstract}
Özet:
Bu araştırmada erken çocukluk döneminde eğitim veren öğretmenlerin acil uzaktan eğitim sürecine dair düşünceleri; süreç içerisinde karşılaştıkları zorluklar ve bu zorlukları nasıl çözüme kavuşturdukları incelenmiştir. Nitel desenlerden durum çalışmasına uygun olarak yapılandırılan araştırmada katılımcılar amaçlı örnekleme yöntemlerinden ölçüt örnekleme yolu ile belirlenmiştir. Bu bağlamda örneklem seçiminde ölçüt olarak öğretmenlerin erken çocukluk dönem çocuklarıyla çalışıyor olmaları ve acil uzaktan eğitim sürecinde eğitim vermiş olmaları belirlenmiştir. Bu yöntemle belirlenen her biri farklı şehir ve okullarda görev yapan 25 erken çocukluk dönem öğretmeni çalışmanın örneklemini oluşturmaktadır. Yarı yapılandırımış görüşme formları ile toplanan araştırma verileri içerik analizi ile incelenmiştir. Araştırma sonuçlarına göre öğretmenler özellikle internet erişimi, materyal ve teknolojik araç gereçlere erişim konusunu göz önüne alarak sürecin fırsat eşitliği ilkesine uygun olarak yapılamadığını, aile yaşantılarının eğitime olumsuz şekilde yansıdığı, alt yapı sorunlarının süreci olumsuz etkilediğini, çocukların ekranda uzun süre kalmaları sonucu sürecin özellikle göz sağlığını olumsuz etkilediğini ve özellikle çocukların bazı gelişim dönemlerinde sorunlar yaşadıklarını belirtmektedir. Bunun yanı sıra öğretmenler acil uzaktan eğitim sürecinde aile-öğretmen iletişimin daha etkin olduğunu öne sürmektedir. Araştırma sonuçlarına bakıldığında salgın ve benzeri olumsuz durumların yakın gelecekte tekrar olabileceği göz önüne alınarak özellikle internet erişimi ve alt yapı gibi sorunların giderilmesi gerekliliği bununla birlikte uzaktan eğitim sürecinde öğrencilerin gelişimsel özellikleri dikkate alınarak hibrit tarzı eğitim modellerinin uygulanması gerektiği önerilmektedir.
\end{abstract}

Anahtar Kelimeler: Erken Çocukluk Dönemi, Acil Uzaktan Eğitim, Erken Çocukluk Dönem Öğretmenleri

\begin{abstract}
:
In this study, the thoughts of teachers who teach in early childhood, about the emergency distance education process; It was aimed to examine the difficulties and problems faced during the process and how they solved them. In the study, which was structured in accordance with the case study, one of the qualitative designs, the participants were determined by sampling criteria in purposeful sampling methods. In this context, it was determined that the teachers were working with early childhood children and provided education in the emergency distance education process as criteria in the selection of samples to represent the universe. 25 early childhood teachers determined by this method, each working in different cities and schools, constitute the sample of the study. The research data collected with semistructured interview forms were analyzed with content analysis. According to the results of the research, teachers especially considering the issue of internet access, access to materials and technological equipment, and that the process cannot be carried out in accordance with the principle of equal opportunity, family life reflected negatively on education, infrastructure problems affect the process negatively, children stay on the screen for a long time, especially the eye health of the process. It states that it affects negatively and especially children experience problems in some developmental periods. In addition, teachers argue that family-teacher communication is more effective in the emergency distance education process. Considering the results of the research, considering that pandemics and similar negative situations may recur in the near future, it is suggested that problems such as internet access and infrastructure should be eliminated, and that hybrid style education models should be implemented by considering the developmental characteristics of students in the distance education process.
\end{abstract}

Keywords: Early Childhood, Emergency Remote Teaching, Early Childhood Educator

\footnotetext{
${ }^{1}$ Pamukklale Üniversitesi, e-posta: aaykar@pau.edu.tr

2 Pamukkale Üniversitesi, e-posta: iyurdakal@pau.edu.tr
} 
Önerilen Atıf Bilgisi/To Cite This Article: Aykar, A. N. ve Yurdakal, İ. H. (2021). Erken Çocukluk Öğretmenlerinin Acil Uzaktan Eğitime İlişkin Görüşleri, Temel Eğitim Dergisi, 3(2), 6-14. ttps://doi.org/10.52105/temelegitim.3.2.1

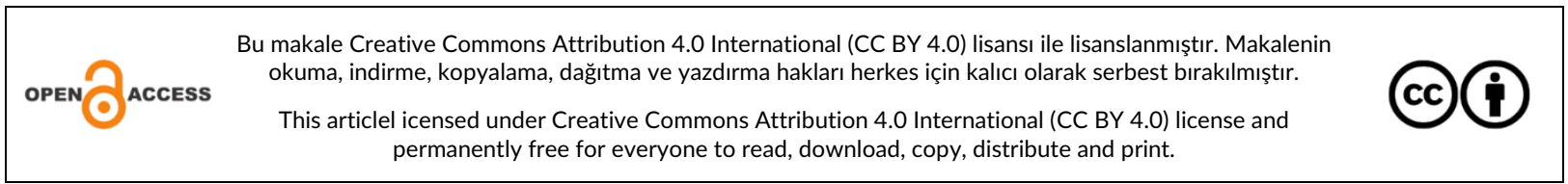

\section{Giriş}

İnsanlığın varoluşundan itibaren üstesinden gelmek zorunda kaldığı krizler, hastalıklar, savaşlar, felaketler olmuştur. Çin'in Wuhan kentinde etkisini göstermeye başlayıp tüm dünyaya yayılan Covid-19 salgını da Dünya Sağlık Örgütü (WHO) tarafından 11 Mart 2020 yılında pandemi olarak kabul edilmiş ve üstesinden gelinmek zorunda olunan bir salgın olmuştur (WHO, 2020). Pandemi etkisinin arttırmasıyla birlikte toplumsal kaygılar artmış (Lin, 2020), eğitim de dâhil olmak üzere hayatın birçok alanında köklü değişikliklere gidilerek önlemler alınmıştır. Uygulamaya geçirilen ev yasakları, seyahat kısıtlamaları, okulların kapatılması gibi önlemler bireylerin eğitimlerine okulda devam edememesine bu durum da eşit eğitim alma hakkında zorluklara neden olmuştur (Giannini \& Lewis, 2020).

Yüz yüze devam eden eğitim-öğretim faaliyetlerine uzaktan eğitim ile devam etme kararı dünya çapından alınmış olan önlemlerden bir tanesidir. Uzaktan eğitim; zaman ve mekân sınırlarının ortadan kalmasını sağlayan, öğrenme faaliyetlerini kullanıcılarına elektronik ortamda sunan, planlı ve tasarlanmış öğrenme faaliyetidir (Altıparmak, 2011). Uzaktan eğitim modeli uzun yıllardır sıklıkla yükseköğretimde 21. yüzyılla birlikte ilk ve orta öğretim kademelerinde kullanılan (Queen \& Lewis, 2011), pandemiyle birlikte tüm örgün kurumlarda kullanılması zorunlu hale gelen bir eğitim modelidir. Birleşmiş Milletler Eğitim, Bilim ve Kültür Örgütü (UNESCO)'nün istatistiklerine göre Türkiye'de 13.01.2021 tarihi itibariyle okulların kapanmasından etkilenmiş olan öğrenci sayısı 24,901,925; dünya genelinde ise bu sayı 251,092,792'dir (2021). Uzaktan eğitim politikasının istenilen seviyede verimlilik ve etkinlikte uygulanabileceğine yönelik birtakım soru işaretleri vardır. Bu soru işaretlerinin oluşmasında etkili olan başıca sorular; öğrenen ve öğretmen hazırlığının nasıl olacağı, herkesin internete ve çevrim-içi eğitim ortamına katılım sağlayabilmesi için gerekli olan donanıma, dijital araçlara erişiminin mümkün olup olmayacağıdır (Muhdi, Nurkolis \& Yuliejantiningsih, 2020). Fırsat eşitsizliğine neden olan bu durumun, eğitim sisteminde zaten var olan eşitsizlikleri arttıracağı, çocukların birçok öğrenme fırsatını kaçırmış olacağı, okullarda sunulan sağlıklı yemeklere erişimin kaybedileceği, ekonomik sorunların ve sosyal stresin artmasına neden olacağı öngörülmektedir (Can, 2020). Aynı zamanda uzaktan eğitimle birlikte öğrenen ve öğreticinin birtakım zorluklar yaşadığı; öğreticilerin sanal sınıf yönetiminde zorlandıkları, dijital araç kullanımında yetersiz olan bireylerin uyum sağlama sürecinde birtakım zorluklar yaşadıkları (Iwai, 2020), öğreticilerin kendilerini baskı altında hissettikleri ve yüz yüze eğitime geçişte normal akışa uyum sağlama konusunda endişe içerisinde oldukları (Burke \& Dempsey, 2020), çocuklarda ekran bağımlılı̆ı eğiliminin arttığı (Akkaş-Bayram, Ocak ve Ocak, 2020) çalışmalar tarafından ortaya koyulmuştur. Bu olumsuzluklara rağmen uzaktan eğitim modelinin etkinliğini gösteren çalışmalar da mevcuttur. Xiao (2018), uzaktan eğitim modelinin yapmış olduğu uygulamalarla kendini kanıtladığını belirtmiş ve uzaktan eğitim modelinin birleştirici ve tamamlayıcı olduğunu vurgulamış, UNESCO (2002) yayımlamış olduğu bir raporda teknik, sosyal ve ekonomik bakımdan değerlendirme yapıldığında uzaktan eğitim modelinin birçok avantaj sağladığını belirtmiştir. Aynı zamanda pratik ve ekonomik olması bakımından dijitalleşmenin eğitimde önemli bir yer edinmiş olması, eğitimin ve iletişimin her şartta devam ettirilebiliyor olması, bireylerin sağılıkı bir şekilde yaşantılarına devam etmelerine olanak tanıması, içe dönük bireylerin sınıf dışı ortamda e posta ya da diğer iletiş̧im araçları aracılığıyla rahat bir şekilde iletişim kurmasını sağlaması, istenilen zaman ve mekânda eğitime erişim imkanı vermesi olarak ortaya koyulmuştur (Frankşin, Yoakam \& Warren, 1996; Baytiyeh, 2019; Burke \& Dempsey, 2020; Iwai, 2020).

Uzaktan eğitimle birlikte teknoloji önceki yaşantımıza göre daha fazla hayatımızda yer almaya başlamıştır. Ancak teknolojinin eğitimde sağladığı faydaların yanı sıra ele alınması gereken diğer faktörler vardır, bunlar eğitimdeki hedef, akademik değerler, paydaşlar, idari yapı, alt yapı, ayrılan bütçe, politik ve ekonomik baskılar gibi değişkenlerdir (Xiao, 2018). Bu değişkenlerin iyi bir şekilde analiz edilmesi ve bu doğrultuda eğitime devam edilmesi önemlidir. Uzaktan eğitime geçişle birlikte öğretmenlere, öğrencilere, ailelere ve politikacılara daha fazla sorumluluk yüklenmiş (Chang \& Satako, 2020), eğitimin devamlıı̆ını sağlamak için ülkeler yenilikler yapmak zorunda kalmış, eğitim sisteminde 
mecburi değişikliklere gidilmiş ve eğitimde dijitalleşmeyle birlikte eğitimin kalitesi dijital erişimin seviyesine ve kalitesine bağlanmıştır (Gilani, 2020). Bahsedilen bu durumlar yapılacak olan çalışmanın temelini oluşturmuş ve erken çocukluk dönem eğitimcilerinin bu süreçte karşılaştığı olumlu durumların, engellerin ne olduğu ve engellere karşı ne gibi çözümler bulduklarını ortaya çıkarmak amaçlanmıştır. Bu amaç doğrultusunda aşağıdaki sorulara yanıt aranmıştır.

1. Erken çocukluk eğitimcilerinin uzaktan eğitim sürecinde karşılaştıkları olumlu durumlar nelerdir?

2. Erken çocukluk eğitimcilerin uzaktan eğitim sürecinde karşılaştıkları zorluklar, engeller nelerdir?

3. Erken çocukluk eğitimcilerinin uzaktan eğitim sürecinde karşılaştıkları engellere nasıl çözüm bulmuşlardır?

\section{Yöntem}

\section{Araştırmanın Modeli}

Erken çocukluk döneminde eğitim veren öğretmenlerin acil uzaktan eğitim sürecine dair düşünceleri; süreç içerisinde karşılaştığı zorlukların, problemlerin ne olduğu ve bunları nasıl çözüme kavuşturduklarını incelemeyi amaçlayan bu çalışmada nitel araştırma desenlerinden durum araştırması yöntemi kullanılmıştır. Creswell'e (2007) göre durum çalışması; araştırmacının zaman içerisinde sınırlandırılmış bir veya birkaç durumu çoklu kaynakları içeren veri toplama araçları (gözlemler, görüşmeler, görsel-işitseller, dokümanlar, raporlar) ile derinlemesine incelediği, durumların ve duruma bağı temaların tanımlandığı nitel bir araştırma yaklaşımıdır. Bu bağlamda araştırmada erken çocukluk öğretmenlerinin acil uzaktan eğitime ilişkin görüşleri derinlemesine incelenmiş ve duruma bağlı temalar tanımlanarak bulgular bu temalar üzerinden incelenmiştir.

\section{Katılımcılar ve Araştırma Bağlamı}

Araştırmanın katılımcıları amaçlı örnekleme yöntemlerinden ölçüt örnekleme yolu ile belirlenmiştir. Ölçüt örnekleme, araştırmacı tarafından daha önceden belirlenmiş olan ölçütleri taşıyan kişilerin araştırmaya dâhil edilmesidir (Creswell, 2017). Bu bağlamda evreni temsil edecek örneklem seçiminde ölçüt olarak öğretmenlerin erken çocukluk çocuklarıyla çalışıyor olmaları, uzaktan eğitim sürecinde eğitim gerçekleştirmiş olmaları belirlenmiştir. Bu yöntemle belirlenen her biri farklı şehir ve okullarda görev yapan 25 erken çocukluk öğretmeni çalışmaya katılmaları için davet edilmiştir. Araştırma kapsamında katılımcılara uzaktan eğitim sürecindeki yaşantılarına ve sürece ilişkin düşüncelerine yer verileceği açıklanmış ve görüşme sorularına yanıt vermeleri istenmiştir. Veriler çevrimiçi görüşmeler yoluyla toplanmış ve bilgisayar ortamına aktarılmıştır.

Çalışmaya katılan öğretmenlerin tamamı resmi veya özel kurumlarda erken çocukluk döneminde bulunan çocuklarla çalışmaktadır. Öğretmenlerin 4'ü 8 yaş, 4'ü 7 yaş, 5'i 6 yaş, 7'si 5 yaş, 4'ü 4 yaş ve 1 tanesi 3 yaş grubunun öğretmenliğini yapmaktadırlar. Etik kurallar çerçevesinde katılımcıların isimlerine yer verilmemiş ve Ö-1, Ö-2 şeklinde kodlamalar yapılmıştır.

\section{Veri Toplama Araçları}

Verilerin toplanmasında öğretmenlerin uzaktan eğitim sürecine ilişkin görüşlerini, karşılaştıkları zorlukları ve çözüm yollarını belirlemeye yönelik araştırmacılar tarafından geliştirilmiş olan yarı yapılandırılmış görüşme formu kullanılmıştır. Görüşme formunun oluşturulma aşamasında alan yazın taraması yapılmış ve bu doğrultuda görüşme maddeleri oluşturulmuştur. Formun son şeklini alması için uzman görüşüne sunulmuş ve gelen dönütler doğrultusunda düzeltmeler yapılarak görüşme formunun son şekli oluşturulmuştur. Yarı yapılandırılmış görüşme formu son haliyle 6 sorudan oluşmaktadır. Sorular öğretmenlerin karşılaştıkları engelleri ve bu engelleri nasıl çözüme kavuşturduklarını anlamaya yöneliktir. Aynı zamanda veri kalitesini arttırmak ve daha detaylı veri akışı sağlayabilmek için neden, niçin sorularına da yer verilmiştir. Verilerin toplanma aşamasında öncelikle öğretmenlere bilgilendirilme yapılmış, görüşmeler çevrimiçi görüntülü programlar aracılığı ile gerçekleştirilmiştir. Görüşmeler sözlü ve görüntülü olarak gerçekleştirilmiş olup ortalama olarak 20-25 dakika sürmüş ve katılımcıların cevapları araştırmacılar tarafından bilgisayar ortamına aktarıımıştır. Creswell'e (2020) göre araştırmacının görüşmeleri yüksek kalitede cihazla kaydetmesi ve ardından bunu yazıya aktarması güvenirliğin arttırılmasını sağlamaktadır. Veri toplama araçları ile araştırmacı katılımcıların gerçek yorumlarına doğrudan ulaşır ve gerçek bilgiye daha yakın olur (Merriam, 2018). Katılımcıların davranışlarını, 
düşüncelerini doğru bir şekilde anlamak, yorumlamak çalışmanın iç geçerliği için önemlidir. Bu doğrultuda bu çalışma kapsamında yazıya aktarılan görüşme cevapları iç geçerliği arttırmak adına katılımcılara gösterilmiş ve katııımcı doğrulaması yapılmıştır. Verilerin analizinde bir başka araştırmacıdan daha yardım alınarak görüş birliği yüzdesi hesaplanmıştır. Hesaplama "güvenilirlik = görüş birliği / görüş birliği +görüş ayrılığı x 100" formülüyle yapılmıştır (Miles ve Huberman, 2015, s. 64). Araştırmacılar arasındaki uyum \%91.3 olarak hesaplanmıştır. Bu oran sonuçların güvenilir olduğunu göstermektedir.

\section{Verilerin Analizi}

Verilerin analiz edilmesinde içerik analiz tekniği kullanılmıştır. İçerik analizi, benzer verilerin temalarla bir araya getirilerek okuyucunun anlayabileceği bir şekilde düzenleyerek yorumlanma sürecidir (Yıldırım ve Şimsek, 2016). Patton'a (2013) göre içerik analizi, hacimli olan nitel materyalin temel tutarlılıklarını ve anlamlarını belirlemek için yapılan anlamlandırma çabasıdır. Bu çalışmada verilerin toplanması ve analizi eş zamanlı olarak gerçekleştirilmiştir. Illk olarak elde edilen verilerin kodlaması ayrı zamanlarda iki araştırmacı tarafından gerçekleştirilmiş̧ir. Kodlama, toplanan verilerden çalışmaya yönelik kesitler elde etmek için verilerin sembolik açıdan kısaltılmasıdır (Merriam, 2018). Oluşturulan kodlamaların karşılaştıııması yapılmıştır. Bu durum araştırmanın güvenirliğini arttırması bakımından önemlidir. Kodlamaların yeniden incelenmesi ve tümevarımsal şekilde ele alınmasıyla birlikte tekrar eden kodlardan temalar oluşturulmuştur.

\section{Bulgular}

Covid-19 salgın döneminde gerçekleştirilen acil uzaktan eğitim sürecinde erken çocukluk öğretmenlerinin karşılaştığı engeller ve bu engellere getirdikleri çözümlerin incelenmesini araştıran bu çalışmanın bulguları yedi tema ile açıklanmıştır. Temalar; fırsat eşitsizliği, aileye bağlı sorunlar, aileeğitimci iş birliği, alt yapı problemleri, aşırı ekran kullanımı, gelişim alanlarının geliştirilememesi, aile ile iletişim olarak belirlenmiştir.

\section{Fırsat Eșitsizliği}

Örgün eğitim ile çocuklara çeşitli imkânlar ve destek sağlanarak aralarında olan fırsat eşitsizliğinin en aza indirgenmesi amaçlanmaktadır. Salgın süreci ile birlikte eğitim kurumları bu amaçlarını sürdürmeye devam etmişlerdir ancak çocukların internete erişim, dijital araçlara erişim gibi durumlarda sorunlar yaşaması fırsat eşitsizliğinin kendini yoğun bir şekilde göstermesine ve sürece ilişkin zorlukların yaşanmasına neden olmuştur. Öğretmenlerin yaşamış olduğu olumsuzluklar/zorluklar ele alındığında bu konuya dikkat çektikleri görülmektedir. Ö-7 'Her çocuğun internete erişim imkânı olmadığı için imkan ve fırsat durumu yeterince sağlanamamış oluyor' ifadesi ile bazı çocukların eğitim sürecinden geri kaldığını, Ö-23 'Kiminin bilgisayarı kiminin telefonu yok özellikle çok çocuklu ailelerde bu daha da problem oluyor. Bazılarının evinde internet bağlantısı dahi yok' ifadeleriyle çocukların dijital erişim araçlarına sahip olmadığı, kalabalık ailelerde dijital araçların yetersiz olduğunu ve durumun eğitimi aksattığını belirtmiştir. Ö-8 'Kaç öğrencimin internete erişimi var, evlerinde dersler için gerekli olan materyaller var?' şeklinde vermiş olduğu yanıt çocukların imkânsızlıklarının eğitimcilerde kaygıya neden olduğunu ve eğitimcinin fırsat eşitsizliğinin oluşma ihtimalini düşündüğünü göstermektedir. Uzaktan eğitim sürecinde fırsat eşitsizliğinin farklı şekillerde kendini gösterdiği ve bu durumun eğitim sürecine olumsuz bir şekilde yansıdığı belirlenmiştir. Fırsat eşitsizlikleri internete erişim, dijital araçlara sahip olma, çocuklar arası bireysel farklılıkların olması, materyal eksiklikleri gibi durumlar ile ifade edilebilir.

Uzaktan eğitim sürecinde çocukların yaşadığı materyal eksikliğini Ö-11 'Çocuklar her zaman materyal açısından hazırıklı olamayabiliyor, o yüzden her zaman minimal olmalıyız. Okul ortamındaki imkânlar herkesin evinde olamıyor maalesef' şeklinde dile getirmiştir. Diğer eğitimcilerden elde edilen veriler bu durumu desteklemektedir. Araştırma sürecinde eğitimcilerin bireysel farklılıkların da fırsat eşitsizliğine neden olduğunu düşündüğüne dair veriler elde edilmiştir. Ö-24 'Uzaktan eğitim sürecinde bireysel farklılıklar göz ardı edilmiş oluyor. Bireysel farklııkları olan çocukların olumsuz etkilendiğini düşünüyorum. Böyle bir deneyim yaşamak istemezdim' şeklinde düşüncelerini ifade etmiştir.

\section{Aileye Bağlı Sorunlar}

Uzaktan eğitim sürecinde eğitimcilerin karşılaşmış olduğu engellerden bir diğeri ise aileye bağlı sorunlar olmuştur. Ö-25'in '...aile içi sorunlar ders sürecine yansıyor' ifadesinden ailelerin yaşadıkları sorunları eğitim sürecine yansıttıkları, çocukların durumunu çok göz önünde bulundurmadıkları ortaya çıkmıştır. Elde edilen verilerle birlikte ailelerin bu süreçte sergiledikleri tutumun çocukları üzerinde de 
olumsuzluklara neden olduğu, çocuklar üzerinde baskı yaptığı ortaya çıkmıştır. Ö-1 bu durumu şu cümleleriyle açıklamıştır:

"Olumsuz olarak karşılaştığım sorun bu süreçte velilerimiz arasındaki rekabet ve çocuklarını başka çocuklarla kıyaslama durumu. Veliyi bu işin içine kattı bu süreç bu çok güzel ama bilinçsiz veliler bu süreçte kendi çocuklarıı psikolojik olarak çok olumsuz etkiliyor. Yüz yüze eğitimde en çok veliden duyduğumuz cümle 'hocam evde çok güzel yapıyor' cümlesiydi ve veli çocuğunun potansiyelinin üstünde şeyler yüklüyordu çocuğa. Bu süreç velilerde biraz farkındalık yarattı çocuğun potansiyelini inkar edemiyor. Daha net görüyor. Kıyaslıyor evet ama bilinçli velide bu farkındalık yaratırken bilinçsiz olanda çocuklara baskı olarak geri dönüyor bu."

Aile tutumlarıyla ilgili olarak eğitimcilerin olumsuz olarak nitelendirdiği bir diğer durum ise ailenin sürekli, saat fark etmeksizin öğretmen ile iletişime geçme isteği olarak belirtilmiştir. Eğitimcilerin bu durumdan oldukça rahatsız oldukları (Ö-2 'Veliler düzensiz saatlerde arama yapabiliyor') hatta bazılarının bunu taciz olarak nitelendirdikleri veriler ile ortaya çıkmıştır. Örneğin;

"Veliler taciz ediyor. Şöyle taciz. Okuldaki gibi uyanınca elini yüzünü yıkayın kahvaltı tarz yönergeler ve plan var. Çocuğunu video çekip aldığı nefesi çekip gönderen var. Öğretmenim yeni uyandım elimi yüzümü yıkıyorum (yıkarken) yatağımı topluyorum (toplarken) biraz taciz olayı fazla ve mesai kavramı yok. Özel hayatımız kalmadı" (Ö-3).

Eğitimciler ailelerin bu süreçte aynı zamanda umursamaz, ilgisiz bir tutum sergilediklerini söylemişlerdir. Bu durum çocuğun öğrenme durumunu olumsuz yönde etkileyebilmektedir. Örneğin;

Ö-3 "Bazı şeylerde kontrol mekanizması velinin desteğine geçti. Bazı veliler ilgisiz telefonlarımızı açmıyor. Mesajları görse de dönüş yapmıyor. Kullandığımız planın profesyonel olduğunu düşünüyorum. Veliler için özel link atıyoruz ve o gün ki etkinlikler için her şey var. Burada sadece veli öğretmen rolüne geçtiği için çocuğun öğrenmesi velinin inisiyatifinde".

\section{Aile-Eğitimci İş birliği}

Uzaktan eğitim aile ile eğitimci arasındaki iş birliğinin artmasını (Ö-12 'verilen ödevlerin takibiyle, ailelerin çocuklarına daha fazla zaman ayırdığını düşünüyorum'), ailelerin sorumluluklarının daha farkında olmasını sağlamış (Ö-9 'Bu süreçte birçok aile çok sorumluluk alıyor ailelere sorumluluk duygusu kazandırdı') ve ailenin eğitim sürecine katııımı artmıştır (Ö-22 'Uzaktan eğitim sayesinde veliler çocuklarının eğitimine daha çok ortak olmaya başladılar. Aile, çocuk, öğretmen iş birliği çok daha kıymetli olmaya başladı').

Aileler uzaktan eğitim sürecinde çocuklarının eğitiminde daha fazla yer almaya başlamış, çocuklarına ve öğretmene destek olma gibi rolleri üstlenmişlerdir. Eğitimciler de bu durumun oldukça farkındadırlar. Örneğin;

'Bu yaş grubunda takip oldukça önemlidir bu nedenle ailelerle geçmişe göre çok daha sılı bir iletişim kurmuş durumdayım. Onlar adeta yardımcı öğretmenlerimiz olmuş durumdalar' (Ö-23).

\section{Alt Yapı Problemleri}

Eğitimcilere göre alt yapı problemleri uzaktan eğitim sürecini olumsuz etkileyen başlıca sorunlardandır (Ö-22 'Teknolojik problemler, paylaşımlarda çocukların ekranı görmemesi gibi sorunlar yaşıyorum', Ö-14 'Internet kaynaklı sorunlar yaşıyorum, ses açma ve kapama gibi').

Alt yapı problemleri yalnızca internet ya da ders için kullanılan programlarla sınırlı kalmamış, eğitim kaynaklarının uzaktan eğitim sürecine uygun olmaması da bu olumsuzluk içerisinde dahil edilmiştir. Ö-1 'Ne yazık ki ne kadar uyarlamaya çalışırsak çalışalım ders kitaplarımızda uzaktan eğitim sürecine uyumlu içerikler yok maalesef bu bizleri çok zorluyor' ifadesiyle durumu açıklamıştır.

\section{Aşırı Ekran Kullanımı}

Uzaktan eğitim sürecinde eğitimin ekranlar aracılığıyla yapılmış olması ve ders saatlerinde çok fazla azaltmaya gidilmemesinden dolayı çocukların ekranda kalma süresinde artış meydana gelmiştir. Ö8 'Teknolojik aletlerin zararlı yönü ortada onlarla zaman geçirmeleri kısıtlanmaları gerekirken iyice arttı tableti olmayan ev nerdeyse kalmadı. Eğlenmeleri ve bir şeyler öğrenmeleri onları bağımlı hale getirebilir maalesef.' İfadeleriyle çocukların ekran bağımlılığının artmasına yönelik endişelerini dile getirmiştir.

Uzaktan eğitim sürecinde ekran bağımlılığının artması yalnızca çocuklar için bir problem değil aynı zamanda eğitimciler için de bir sorun olmuştur. Örneğin; 
"Uzaktan eğitim = Ekran Bağımlılı̆ı. 14 yıllık öğretmenim ilk defa mesleğimden soğudum Online eğitim ilk başlarda iyi gibiydi ancak sonra faydasının da çok sınırlı olduğunu görünce ve günde 6 saat ekrana maruz kalınca tüm motivasyonumu kaybettim" (Ö-13).

\section{Gelişim Alanlarının Desteklenememesi}

Erken çocukluk dönemi çocukların tüm gelişim alanlarının desteklenmesi ve geliştirilmesi için kritik bir dönemdir (Berk, 2013). Uzaktan eğitim sürecinde eğitimciler çocukların tüm gelişim alanlarının desteklenemediği belirtmiş. Çocukların sosyal gelişimlerinin desteklenememesini 'Ö-4 'Erken çocukluk dönemi çocukları evden fazla çıkamadıkları için deneyimsel öğrenme konusunda kısıtı kaldılar. Yaşıtlarıyla bir arada olamadıkları için sosyal öğrenmeleri, iletişim becerileri açısından eksiklikler söz konusu' ifadesiyle belirtmiştir. Ayrıca eğitimciler çocukların aynı zamanda kas gelişimlerinin de ekran aracılığıla yeterince desteklenemediğini belirtmiştir (Ö-24 'Ders esnasında iletişim kurmakta, yaşayarak öğrenme durumlarında zorluklar yaşanıyor. Çocukların sosyal becerileri, büyük-küçük kas gelişimleri yeterince desteklenmiyor. $O$ yüzden bu dönem çocukları için uzaktan eğitim uygun değil').

\section{Aileyle İletişim}

Eğitimcilerin karşılaştıkları problemleri çözüme kavuşturmak için kullanmış oldukları yöntemin aile ile iletişime geçme olduğu tespit edilmiştir. Ö3 'Okul evime yakın gidip malzeme alıp geliyorum. Materyalleri okuldan ödünç alıyorum. Internetten renkli çıktı alıp ailelere ulaştırıyor, evdeki imkanlarla alternatif etkinlikler üretiyorum' ifadesi ile erişim sağlayamayan çocukların aileleri ile iletişime geçerek aile aracılığı ile çocuğa ulaşıp problemi çözmeye çalıştığı görülmektedir.

Materyal eksikliği ile ilgili problemi çözmek için eğitimcilerin yine aile ile iletişime geçerek onlara materyal desteğini okuldan temin edip elden vererek çözdükleri dile getirilmiştir. Ö-22 bu durumu şu ifadeler ile açıklamıştır:

"WhatsApp kanalıyla öğreneceğimiz şarkıları, spor videolarını yolluyorum. Fotokopi çekerek ailelere elden ulaştırıyorum".

Gelişim alanlarının desteklenmesine yönelik çözüm bulmak konusunda da eğitimcilerin aile ile iletişime geçtiği, aileler aracılığı ve desteği ile çocukların gelişim alanlarını desteklemeye çalıştıkları görülmektedir. Ö-4 'Her gelişim alanın hitap eden güncel çalışmaları araştırıp belli bir plan dâhilinde sistemli olarak çocuklara vermeye çalışıyor, ailelerle iletişime geçerek onlara açıklamalar yapıyor ve dokümanlar aracılığıyla paylaşıyorum' ifadesi ile olumsuz durumla baş etme yöntemini açıklamıştır. Gelişim alanlarının bu süreçte yeterince desteklenmediğini düşünen eğitimciler ailelere farklı kaynak, yayın önerilerinde de bulunmaktadırlar (Ö-23 'WhatsApp aracılığıyla ailelere ders haricinde çocukların farklı gelişim alanlarına hitap eden yayınlar, kitaplar, kaynaklar, linkler tavsiye ediyorum').

\section{Tartışma ve Sonuç}

Bu çalışmada, covid-19 salgın sürecinde gerçekleştirilen uzaktan eğitim sürecinde erken çocukluk öğretmenlerinin karşılaşmış olduğu olumlu durumlar, engeller, bu engellere getirdikleri çözümleri incelemiştir. Çalışmada elde edilen veriler fırsat eşitsizliği, aileye bağlı sorunlar, aile-eğitimci işbirliği, alt yapı problemleri, aşırı ekran kullanımı, gelişim alanlarının desteklenememesi ve aile ile iletişim olarak adlandırılan yedi tema ile açıklanmıştır.

Fırsat ve imkân eşitliği 1739 sayılı Milli Eğitim Temel Kanunu'nda yer alan temel ilkelerden birisidir (Milli Eğitim Temel Kanunu, 1973). Bu ilke kapsamında eğitimde kadın, erkek herkese fırsat ve imkan eşitliği sağlanması gerekmektedir. Özellikle acil uzaktan eğitim sürecinde internet alt yapısı ve teknolojik araç gereçler (bilgisayar, tablet ve telefon gibi) eğitim-öğretim sürecinin niteliği açısından önem arz ettiğinden bu iki değişken uzaktan eğitimin temelini oluşturmaktadır. Yetersiz internet hızı ve yetersiz teknolojik araçlar süreci sekteye uğratabilmektedir. Bu kapsamda acil uzaktan eğitim sürecinde bazı öğrenciler bu iki değişken açısından süreçte olumsuzluklar yaşamıştır bu da fırsat ve imkan eşitliğine ters bir durum oluşturmaktadır. Nitekim araştırmada öğretmenler bu durumu vurgulamışlardır. Bunun yanı sıra bazı öğrencilerin evlerinde yetersiz araç-gereç olması da aktiviteleri dolayısı ile eğitimöğretim sürecinin kesintiye uğratmıştır. Can (2020), Doğan ve Koçak (2020), Yıldırım (2020) ve Yurdakal (2019) araştırmalarında uzaktan eğitimde alt yapı, teknolojik araç-gereçler ve internet hızı olumsuzluklarına atıfta bulunmaktadırlar. Kocayiğit ve Uşun (2020) ise araştırmalarında öğretmenlerin uzaktan eğitime ilişkin olarak gördükleri en önemli avantajın mevcut eğitimin dışında kalan bireylere eğitim-öğretim olanağı sağlaması olduğunu belirtmektedir. Söz konusu araştırma sonuçları çalışma ile ters sonuçlar ortaya koymaktadır. 
Araştırmaya göre ailelerin yaşadıkları sorunları eğitim sürecine yansıttıkları, çocukların durumlarını göz önünde bulundurmadıkları ortaya çıkmıştır. Elde edilen verilerle birlikte ailelerin bu süreçte sergiledikleri tutumun çocukları üzerinde de olumsuzluklara neden olduğu, çocuklar üzerinde baskı yaptığı ortaya çıkmıştır. Ailelerin sürece karşı olumlu tutum sergilememeleri çocukların da süreçten kopmalarına yol açmaktadır. Özellikle ailelerin çocukla birlikte sürece katılmaması ve çocuğa süreçte rehberlik yapmaması çocuğu süreçte yalnızlaştırmakta ve sürecin niteliğini düşürmektedir. Bunun yanı sıra öğretmenler özellikle ailelerin zaman gözetmeksizin öğretmenlerle iletişime geçmek istemeleri bu durumun da öğretmenler üzerinde olumsuz bir baskı unsuru olduğu tespit edilmiştir. Acil uzaktan eğitim süreci ile birlikte öğretmenler, ailelerin eğitim-öğretim sürecine daha fazla katılım gösterdiklerini belirtmektedir. Beydoğan'a (2006) göre aileleri formal eğitim sürecine katılan çocuklar, aileleri formal eğitim sürecine katılmayan çocuklardan daha avantajı konuma gelmektedir. Çelenk (2003) çalışmasında, aile katııııının çocuğun okul başarısını artırdığı sonucuna ulaşmıştır. Bu kapsamda acil uzaktan eğitim sürecinde ailelerin eğitim-öğretim sürecine katılımlarının artması olumlu bir gelişme olarak görülebilir. Öğretmenler süreçte alt yapı ve internet hızı gibi durumların süreçte sorunlar yaşanmasına yol açtığını öne sürmektedir. Nitekim Yılmaz, Güner, Mutlu, Doğanay ve Yılmaz (2020) ve Arslan ve Şumuer (2020) benzer sonuçlara ulaşmıştır.

Uzaktan eğitim süreçlerinde öncelikle planlılık esastır. Süreci planlayanların uzaktan eğitim sürecine başlamadan önce gerekli internet hızı ve alt yapıyı kullanıcı yoğunluğuna göre ayarlamaları ve süreçte yaşanabilecek sorunlara ilişkin ivedilikle çözüm önerileri üretebilecek bir düzenleme yapmaları beklenmektedir. Ancak salgın ile birlikte planlı bir uzaktan eğitim yerine acil uzaktan eğitime geçilmiş olup bu süreçte alt yapı sorunları gündeme gelmiştir. Bu durum sürecin "acil" olması nedeniyle makul görülebilir ancak salgının uzaması ile birlikte gerek internet erişiminin yaygınlaştııılması gerekse alt yapı problemlerinin çözülmesi ile bu sorun giderek azaltılmıştır.

Çocukların yaşamları, doğumdan itibaren ekran önünde geçmekte ve televizyon izlemek için ayrılan süre, erken çocukluk döneminden başlayarak ergenlik dönemine kadar artarak devam etmektedir (Sevindik, 2011). Teknoloji ve bilgi çağında özellikle küçük yaş çocuklarını olumsuz etkileyen olguların başında ekran bağımlılığı gelmektedir. Ekran bağımlıığının artması ile birlikte özellikle göz sağlığı olumsuz etkilenmektedir. Ekran bağımlıı̆ı̆ının artması çocukların akranları ile yüz yüze iletişiminin ve grup aktivitelerinin azalmasına yol açtığı bilinmektedir (Rosen vd. 2014). Nitekim araştırma sonuçlarına bakıldığında öğretmenlerin özellikle çocuklarda uzun süreli ekran başında ders dinlemelerinin ekran bağımlıı̆̆ına yol açtığına ilişkin görüşleri dikkat çekmektedir. Bu kapsamda özellikle küçük yaş çocuklarında uzaktan eğitimin en büyük sakıncası ekran bağımlılığı olduğu söylenebilir.

Erken çocukluk dönemi, çocukların tüm gelişim alanlarının desteklenmesi ve geliştirilmesi için kritik bir dönemdir. Uzaktan eğitim sürecinde öğretmenler özellikle kritik dönemde kazanılması gereken bir takım gelişimsel ödevlerin pandemi sürecinde edinilemediğini bu durumun da ileriki süreçlerde çocuklar üzerinde olumsuz etkiler oluşturabileceğini belirtmektedirler. Bu kapsamda özellikle fiziksel gelişim ödevlerinin uzaktan eğitim ile kazandırılamayacağı bilinen bir gerçektir. Bu kapsamda hibrit eğitimin önemini bir kez daha vurgulamak gerekmektedir. Doering'e (2006) göre hibrit eğitim, öğrenme ortamının harmanlandığı bir eğitim modeli olup, yüz yüze sınıf ortamlı öğretim ile online ortamlı öğretimin birlikte kullanılmasıdır. Hibrit eğitimin temel amacı iki farklı öğretim modelini birleştirerek daha etkili ve efektif bir öğretim deneyimi sunmaktır (Kumar, 2012). Bu bağlamda hibrit eğitim ile uzaktan verilemeyecek olan özellikle pratik derslerin ya da pratik kazanımların yüz yüze, teorik derslerin ya da teorik bilgilerin ise uzaktan verilmesi erken yaş çocukları için etkili bir model olarak sunulabilir. Araştırma sonucunda şu öneriler sunulabilir:

- Ailelere uzaktan eğitim sürecine çocuklarına nasıl rehberlik yapabileceklerine ilişkin eğitimler verilmelidir.

- Pratik becerilerin uzaktan eğitim ile verilemeyeceği bir gerçek olup bu tarz becerilerin yüz yüze verilmesi gerekmektedir.

- Uzaktan eğitim birtakım sebeplerden ötürü fırsat ve imkan eşitliği ilkesine ters düşebilmektedir. Özellikle yönetim erklerinin bu duruma dikkat etmesi gerekmektedir.

- Uzaktan eğitim sürecinde alt yapı düzenlemelerinin yapılması ve süreçte ortaya çıkabilecek sorunlara ilişkin çözüm önerilerinin süreç başlamadan tamamlanması gerekmektedir.

- İnternet hızının eğitim-öğretim faaliyetlerini aksatmayacak şekilde olması gerekmektedir. 
- Uzaktan eğitim sürecinde aileye bağlı sorunların eğitime yansıma gerekçeleri tespit edilmeli ve bu duruma yönelik önlemler alınmalıdır.

\section{Kaynakça}

Altıparmak, M. (2011). E-öğrenme ve uzaktan eğitimde açık kaynak kodlu öğrenme yönetim sistemleri. Malatya: Akademik Bilişim'11 - XIII. Akademik Bilişim Konferansı Bildirileri Kitabı, 319-327.

Baytiyeh, H. (2019). Why school resilience should be critical for the post-earthquakere covery of communities in divided societies. Education and Urban Society, 51(5), 693-711.

Berk, L. E. (2013). Bebekler ve çocuklar. N. Işıkoğlu Erdoğan (Çev. Ed.). Ankara: Nobel Akademik Yayıncılık

Beydoğan, H. Ö. (2006). Ailelerin eğitim sürecine katılımına yönelik modeller ve yaklaşımlar, Gazi Üniversitesi Kırşehir Eğitim Fakültesi Dergisi, 7(1), 75-90.

Burke, J. \& Dempsey, M. (2020). COVID-19 Practice in primaryschools in Ireland report. National University of Ireland Maynooth, Ireland. https://www.into.ie/app/uploads/2020/04/COVID-19-Practice-in-Primary-SchoolsReport- 1.pdf. adresinden erişilmiştir.

Can, E. (2020). Coronavirüs (Covid-19) pandemisi ve pedagojik yansımaları: Türkiye'de açık ve uzaktan eğitim uygulamaları. Açık Öğretim Uygulamaları ve Araştırma Dergisi, 6(2), 11-53.

Chang, G. C. \& Satako, Y. (2020). How are countries addressing the Covid-19 challenges in education? A snapshot of policy measures. https://gemreportunesco.wordpress.com/2020/03/24/how-are-countriesaddressing-the-covid-19-challenges-in-education-a-snapshot-of-policy-measures/_adresinden 05.01.2021 tarihinde erişilmiştir.

Creswell, J. W. (2007). Qualitative inquiry \& research design: Choosing among five approaches (2. Baskı). USA: SAGE Publications.

Creswell, J. W. (2017). Araştırma deseni: Nitel, nicel ve karma yöntem yaklaşımları. (çev. S. B. Demir). Ankara: Eğiten Kitap.

Creswell, J. W. (2020). Nitel araştırma yöntemleri: Beş yaklaşıma göre nitel araştırma ve araştırma desenleri. (çev. M. Bütün ve S. B. Demir). Ankara: Siyasal Kitapevi.

Çelenk, S. (2003). Okul başarısının ön koşulu: Okul aile dayanışması", ilköğretim Online, 2(2), 28-34.

Doğan, S. ve Kocak, E. (2020). EBA sistemi bağlamında uzaktan eğitim faaliyetleri üzerine bir inceleme. Ekonomi ve Sosyal Araştırmalar Dergisi, 7(14). 110-124.

Ekiz, D. (2003). Eğitimde araştırma yöntem ve metodlarına giriş. Ankara: Anı Yayıncılık.

Giannini, S. \& Lewis, G. S. (2020). Three ways to plan for equity during the coronavirus school closures. https://gemreportunesco.wordpress.com adresinden 11.02.2021 tarihinde erişilmiştir.

Gilani, I. (2020). Coronavirus pendemic reshaping global education system? https://www.aa.com.tr/en/education/coronavirus-pandemic-reshaping-global-educationsystem/1771350 adresinden 05.01.2021 tarihinde erişilmiştir.

Iwai, Y. (2020). Online Learning during the COVID-19 Pandemic: What do we gain and what do we lose when classrooms go virtual?', Scientific American. https://blogs.scientificamerican.com/observations/onlinelearning-during-the-COVID-19- pandemic adresinden 06.01.2021 tarihinde erişilmiştir.

Kocayiğit, A. ve Uşun, S. (2020). Milli Eğitim Bakanlığı'na bağlı okullarda görev yapan öğretmenlerin uzaktan eğitime yönelik tutumları (Burdur ili örneği). Avrasya Uluslararası Araştırmalar Dergisi, 8(23), 285-299.

Lin, C. Y. (2020). Social reaction toward the 2019 novel coronavirus (COVID-19). Social Health Behaviour, 3, 1-2.

Merriam, S. B. (2018). Nitel araştırma. Desen ve uygulama için bir rehber. (çev. S. Turan). Ankara: Nobel Akademik Yayıncilık.

Miles, M. B. \& Huberman, A. M. (2015). Nitel veri analizi, (Edi. S. Akbaba and A-A. Ersoy), Ankara: Pegem Akademi.

Milli Eğitim Temel Kanunu (1973). https://www.mevzuat.gov.tr/MevzuatMetin/1.5.1739.pdf adresinden 23.03.2021 tarihinde erişilmiştir.

Muhdi, N. \& Yuliejantiningsih, Y. (2020). The implementation of online learning in early childhood education during the Covid-19 Pandemic. Jurnal Pendidikan Usia Dini. 14(2), 247-261.

Patton, M. Q. (2013). Nitel araştırma ve değerlendirme yöntemleri. (çev. M. Bütün ve S. B. Demir). Ankara: Pegem Akademi.

Rosen, L. D., Lim, A., Felt, J., Carrier, L. M., Cheever, N. A., Lara-Ruiz, J., \& Rokkum, J. (2014). Media and technology use predicts ill-being among children, preteens and teenagers independent of the negative health impacts of exercise and eating habits. Computers in Human Behavior, 35, 364-375.

Queen, B., \& Lewis, L. (2011). Distance education courses for public elementary and secondary school students: 200910 (NCES 2012-009). U.S. Department of Education, National Center for Education Statistics.

UNESCO (2002). Open and distance learning - Trends, policy and strategy considerations, Paris, FR.

UNESCO (2021). Covid-19 impact of education data. https://en.unesco.org/covid19/educationresponse adresinden 13.01.2021 tarihinde erişilmiştir.

World Health Organization (WHO) (2020). WHO director-genaral's opening remarks at the media briefing on Covid-19. https://who.int/dg/speeches/detail adresinden 02.01.2021 tarihinde erişilmiştir.

Xiao, J. (2018). On the margins or at the center? Distance education in higher education. Distance Education, 39(2), 259-274. 
Yıldırım, A. ve Şimşek, H. (2016). Sosyal bilimlerde nitel araştırma yöntemleri. Ankara: Seçkin Yayınları.

Yıldırım, K. (2020). İstisnai bir uzaktan eğitim-oğretim deneyiminin oğrettikleri. Alanyazın, 1(1). 7-15.

Yılmaz, E., Güner, B., Mutlu, H., Doğanay, G. ve Yılmaz, D. (2020). Veli algısına göre pandemi dönemi uzaktan eğitim sürecinin niteliği. Konya: Palet.

Yurdakal, I. H. (2019). Views of undergraduate students and lecturers on distance education, International Online Journal of Educational Sciences, 11(3), 207-221. 